\title{
TITLE:
}

\section{Video-EEG monitoring in a geriatric veteran population(Abstract_要旨)}

$\operatorname{AUTHOR}(\mathrm{S})$ :

Kawai, Makoto

\section{CITATION:}

Kawai, Makoto. Video-EEG monitoring in a geriatric veteran population. 京都大学, 2008, 博士(医学)

ISSUE DATE:

2008-05-23

URL:

http://hdl.handle.net/2433/124324

RIGHT: 


\begin{tabular}{|l|l|c|l|}
\hline 京都大学 & 博士 (医学) & 氏 名 & 河合 真 \\
\hline 論文題目 & $\begin{array}{l}\text { Video-EEG monitoring in a geriatric veteran population } \\
\text { (高齢退役軍人における脳波ビデオ記録) }\end{array}$ \\
\hline
\end{tabular}

\section{(論文内容の要旨)}

背景 脳波ビデオ同時記録はてんかん発作が疑われる患者を評価するための標準的な方 法になっている。しかしながらこの方法は多くの場合難治性てんかんに対寸る外科的手術 の術前評価の方法として比較的若年者を対象に行われてきている。高齢者のてんかん患者 を対象としたデータは乏しい。また米国における高齢退役軍人を対象としたデータはいま だに発表されていない。米国においては退役軍人専用の病院が存在し、民間の健康保険機 構とは異なる保険システムで運用されている。

目的 高齢、男性優位、慢性疾患率が高いなどの特徴がある退役軍人の患者グループにお ける脳波ビデオ同時記録の傾向と意義を明らかにする。

対象及び方法 米国テキサス州ヒューストン市にあるマイケル・E・ディベーキー退役軍 人病院で1999年から 2006 年の間に脳波ビデオ同時記録を行った 60 歳以上の患 者 71 人を対象として後ろ向き研究を行った。

結果 平均年齢は 68 歳、 $94 \%$ は男性であった。記録中典型的発作は 71 人中 34 人 (4 $8 \%)$ に生じた。典型的発作のうち 12 人 (3 5\%) はてんかん発作であり大部分 $(75 \%)$ は側頭葉てんかん発作であった。残りの 22 人（6 5\%）は非てんかん発作であった。非 てんかん発作のうち 10 人 (4 5\%) は転換障害などの精神疾患に由来寸ると考えられる 精神性非てんかん発作であり、1 2 人 (5 5\%) は生理性非てんかん発作であった。これ らの非てんかん発作と診断された患者 22 人のうち 14 人（6 4\%）に抗てんかん薬が処 方されていた。

考察 今までに発表されている一般の高齢患者を対象とした論文のデータと比較して、退 役軍人を対象とした今回の調查では非てんかん発作が多いことが示された。対象とした患 者グループの特殊性を反映していると考えられる。非てんかん発作の内訳で比較すると生 理性非てんかん発作の割合が多少高かったが、精神性非てんかん発作もよく認められた。 抗てんかん薬が非てんかん発作の患者の多くに処方されていた。てんかん発作の大部分は 側頭葉てんかん発作であった。

結論 脳波ビデオ同時記録は高齢患者における発作性イベントを解明し、正しい治療を行 う上で有用であると考えられた。
（論文番査の結果の要旨）

脳波ビデオ同時記録は多くの場合、難治性てんかんに対する外科的手術の術前評価とし て行われ、高齢者の患者を対象としたデータは乏しい。

申請者は、米国ヒューストン市にある退役軍人病院で、1999年から2006年の間に脳波 ビデオ同時記録を行った60歳以上の難治性発作性疾患患者 71 人を対象として、後ろ向き研 究を行った。平均年齢は68歳、94\%は男性であった。記録中典型的発作は 71 人中 $48 \%$ に生 じた。典型的発作のうち $35 \%$ はてんかん発作で、残りの65\%は非てんかん発作であること が脳波記録により明らかになった。非てんかん発作のうち $45 \%$ は転換性ヒステリーなどの 精神性非てんかん発作であり、55\%はめまいなどの生理性非てんかん発作であった。これ らの非てんかん発作と診断された患者のうち、64\%に抗てんかん薬が処方されていた。

今回の研究において、高齢者の難治性発作性疾患に非てんかん発作が多いことが示され た。これらの非てんかん発作は、生理性非てんかん発作の割合が精神性非てんかん発作よ りも若干高く、これらの患者の多くに抗てんかん薬の処方がされていたことは注目され

る。脳波ビデオ同時記録を用いることで難治性発作性疾患の治療を適切におこなえる可能 性が示唆された。

以上の研究は高齢患者における発作性イベントを解明し、医学的なてんかんの診断と治療 に寄与寸るところが多い。したがって、本論文は博士(医学)の学位論文として価值あるも のと認める。

なお、本学位授与申請者は平成 20 年 3 月 25 日実施の論文内容とそれに関連した研究分野 並びに学識確認のための試問を受け、合格と認められたものである。 